\title{
Fatal aplastic anaemia and liver toxicity caused by D-penicillamine treatment of rheumatoid arthritis
}

\author{
B FISHEL, M TISHLER, D CASPI, AND M YARON \\ From the Department of Rheumatology, Ichilov Hospital, Tel Aviv Medical Center, and the Tel Aviv \\ University Sackler Faculty of Medicine, Tel Aviv, Israel
}

SUMMARY A 65 year old woman with rheumatoid arthritis developed marrow aplasia and jaundice owing to D-penicillamine treatment. Recovery of bone marrow was ineffective, and the patient finally died despite intensive therapeutic measures. The rare coexistence of myelotoxicity and hepatotoxicity is presented and discussed.

Key words: marrow aplasia, hepatotoxicity.

Penicillamine has been used for the treatment of rheumatoid arthritis (RA) since $1964^{1}$ and its efficacy

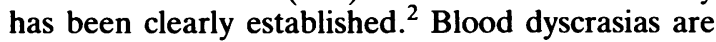
among the most serious adverse effects of this drug, and fatal reactions associated with bone marrow aplasia have been reported. ${ }^{34}$

Hepatotoxicity is a rare complication of penicillamine treatment. ${ }^{5}$ Usually all liver abnormalities resolve when the drug is withdrawn. The association of bone marrow aplasia and hepatotoxicity has not been reported in the past.

We report a case of fatal aplastic anaemia and jaundice caused by D-penicillamine treatment for RA.

\section{Case report}

A 65 year old woman had a two year history of seropositive erosive RA. After treatment with a variety of non-steroidal anti-inflammatory drugs she was given gold injections (aurothiomalate). Gold treatment was discontinued owing to recurrent episodes of leucopenia. Because of active polyarthritis and severe disability treatment was started with D-penicillamine $125 \mathrm{mg} /$ day, which was increased to $250 \mathrm{mg} /$ day after five weeks. Her clinical condition improved and the active synovitis subsided, enabling her to stop all other drugs except for sporadic paracetamol plus propoxyphene preparation. Periodic white blood cell and platelet counts were normal. Three months after D-penicillamine was started petechia and purpura appeared on the legs,

Accepted for publication 30 November 1988.

Correspondence to Dr B Fishel, Department of Rheumatology, Ichilov Hospital, Tel Aviv, Israel 64239. arms, and trunk. D-Penicillamine was stopped, and the patient was admitted to hospital.

Physical examination showed purpuric lesions spread on large areas of skin. No lymphadenopathy or splenomegaly were found. The haemoglobin was $67 \mathrm{~g} / \mathrm{l}$ and the white blood cell count $3 \times 10^{9} / 1$ (94\% lymphocytes, $4 \%$ monocytes, and $2 \%$ segmented neutrophils). Platelet count was $10 \times 10^{9} / 1$, and bone marrow aspiration showed absence of megakaryocytes, erythropoietic and granulopoietic cells with a relative increase of lymphocytes and mast cells. A diagnosis of aplastic anaemia was made, and supportive treatment, including packed red blood cells and transfusion of platelets, was given. Although no signs of infection were noted, the patient was treated with antibiotics (gentamicin and cephazolin). Two days after D-penicillamine was stopped jaundice was noted and laboratory tests showed a bilirubin concentration of $170 \mu \mathrm{mol} / \mathrm{l}$ (mostly direct), serum aspartate transaminase $80 \mathrm{IU}$ (normal up to $40 \mathrm{IU}$ ), lactic dehydrogenase $420 \mathrm{IU}$ (normal up to $300 \mathrm{IU}$ ), and alkaline phosphatase $120 \mathrm{IU}$ (normal up to $90 \mathrm{IU}$ ). Haemolysis was ruled out, however, by a negative Coombs' test and normal concentrations of haptoglobin. The patient's situation deteriorated despite intensive treatment with corticosteroids, lithium carbonate, and repeated blood transfusions. Jaundice became more profound, renal failure developed, and the patient died on her 17 th day in hospital. A necropsy was not performed.

\section{Discussion}

Although D-penicillamine has been found to be an 
efficient drug in the treatment of RA, the total complication rate in several studies has been as high as $70 \%$, and in one study about one third of the patients' treatment had to be stopped. ${ }^{6}$ Most side effects are not severe and resolve when D-penicillamine is discontinued. The most serious and occasionally fatal complication is bone marrow aplasia. Usually bone marrow depression develops gradually, but sudden onset of marrow aplasia has been reported previously. ${ }^{34}$ The mechanism of myelotoxicity is not fully understood, but idiosyncrasy $^{7}$ and drug interference with the synthesis of DNA $^{8}$ have been suggested. Association of myelotoxicity with HLA-DR $4^{9}$ and with sulphoxidation capacity ${ }^{10}$ has been documented.

Hepatotoxicity due to penicillamine treatment has been reported rarely. The mechanism of liver toxicity in most .cases is hypersensitivity and it is commonly associated with skin eruption and eosinophilia. ${ }^{5}$ Fatal cholestatic jaundice has been described $^{11}$; liver abnormalities, however, are usually mild and resolve when the drug is stopped. Although our patient had received a blood transfusion before the appearance of jaundice, this did not seem to be related to the transfusion as bilirubinaemia was direct, liver enzymes were increased, and the concentrations of haptoglobin were preserved.

It has been suggested that marrow depression may be more common in patients who have developed haematological abnormalities in previous gold treatment. ${ }^{12}$ Indeed, in our patient gold had been stopped four years earlier because of recurrent leucopenia. Elderly patients may be at greater risk, ${ }^{13}$ though this observation has not been confirmed. ${ }^{14}$

Although separate descriptions of hepatotoxicity and bone marrow aplasia have been reported, the present concomitance of these serious side effects unique, re-emphasizing the hazards of D-penicip lamine treatment.

\section{References}

1 Jaffe I A. Rheumatoid arthritis with arteritis. Report of a ca\& treated with penicillamine. Ann Intern Med 1964; 61: 556-63.

2 Multicenter trial group. Controlled trial of D-penicillamine m severe rheumatoid arthritis. Lancet 1973; i: 275-80.

3 Kay A G L. Myelotoxicity of D-penicillamine. Ann Rheum Dag 1979; 38: 232-6.

4 Ramselaar A C P, Dekker A W, Huber-Bruning O, Bijlsm J W J. Acquired sideroblastic anaemia after aplastic anaemia caused by D-penicillamine therapy for rheumatoid arthritiso Ann Rheum Dis 1987; 46: 156-8.

5 Rosenbaum J, Katz W A, Schumacher H R. Hepatotoxici associated with use of D-penicillamine in rheumatoid arthritiso Ann Rheum Dis 1980; 39: 152-4.

6 Weiss A S, Markenson J A, Weiss M S, Kammerer W $\mathbf{F}$ Toxicity of D-penicillamine in rheumatoid arthritis. Am J Med 1978; 64: 114-22.

7 Jaffe 1 A. Penicillamine. In: McCarty D J, ed. Arthritis a allied conditions. 10th ed. Philadelphia: Lea and Febiger, 1985t $502-11$.

8 Chandra $P$, Koch W. Cited in report of symposium on penf cillamine. Ann Rheum Dis 1975; 34: 273-4.

9 Panayi G S, Wooley P, Batchelor J R. Genetic basis of rheumatoid disease: HLA antigens, disease manifestations, ant toxic reactions to drugs. $\mathrm{Br}$ Med $J$ 1978; ii: 1326-8.

10 Emery P, Panayi G S, Huston G, et al. D-penicillamine induced toxicity in rheumatoid arthritis: the role of sulphoxidation statis and HLA-DR3. J Rheumatol 1984; 11: 626-32.

11 Barzilai D, Dickstein G, Enat R, Bassah H, Lichtig C, Gellei $\overrightarrow{\bar{B}}$ Cholestatic jaundice caused by D-penicillamine. Ann Rheun Dis 1978; 37: 98-100.

12 Webley $\mathrm{M}$, Coomes $\mathrm{E} \mathrm{N}$. Is penicillamine therapy in rheumato arthritis influenced by previous treatment with gold? $\mathrm{Br}$ Med 1 1978; ii: 91.

13 Jaffe I A. D-penicillamine. Bull Rheum Dis 1977; 28: 948-53?

14 Kean W F, Anastassiades T P, Dwosh J L, Ford P M, Kelly W Q Dok C M. Efficacy and toxicity of D-penicillamine for rheum? toid disease in the elderly. J Am Geriatr Soc 1982; 30: 94-100 